Jurnal KONTEKSTUAL

Volume 01, No. 1, Agustus 2019, pp. 33-38

\title{
PENGARUH MOTIVASI KERJA DAN KINERJA GURU TERHADAP PENGELOLAAN KELAS DI SDN SIWUNGKUK 01 WANASARI BREBES
}

\author{
Lutfiyatun Chasanh $^{1}$, Moh. Toharudin ${ }^{* 2}$, Didik Tri Setiyoko ${ }^{3}$ \\ Prodi Pendidikan Guru Sekolah Dasar, Fakultas Keguruan dan Ilmu Pendidikan, \\ Universitas MuhadiSetiabudiBrebes, Indonesia \\ Email corresponden: *sunantoha12@gmail.com
}

\begin{abstract}
Abstrak
Penelitian ini bertujuan untuk mengetahui pengaruh motivasi kerja dan kinerja guru terhadap pengelolaan kelas di sekolah dasar negeri. Penelitian ini menggunakan metode kuantitatif dengan desain penelitian korelasi Teknik pengambilan sampel dilakukan dengan teknik sampel jenuh untuk pengambilan semua anggota sebagai sempel. Teknik pengumpulan data untuk motivasi kerja, kinerja guru dan pengelolaan kelas berupa angket. Teknik analisis data yang digunakan adalah stsistik deskripsi, uji normalitas, uji linearitas dilakukan sebagai uji prasyarat hipotesis, uji t untuk pengujian hipotesis. Adapun hasil yang diperoleh dari hasil uji t melalui perhitungan SPSS 16, diperoleh nilai signifikasi yang menunjukkan bahwa $\mathrm{H}_{o}$ ditolak yang berarti bahwa $H_{a}$ diterima. Sehingga, motivasi kerja memberikan pengaruh terhadap pengelolaan kelas pada sekolah dasar. Pada hasil kinerja guru dari hasil uji t melalui perhitungan SPSS 16, diperoleh nilai signifikasi yang menunjukkan $\mathrm{H}_{o}$ ditolak dan $\mathrm{H}_{a}$ diterima. Dengan demikian kinerja guru memberikan pengaruh terhadap pengelolan kelas Sekolah Dasar. Jadi dapat Kesimpulan dari penelitian ini yaitu ada pengaruh sikap motivasi kerja dan kinerja guru terhadap pengelolaan kelas. Oleh karena itu motivasi kerja yang dimiliki oleh masingmasing guru berpengaruh terhadap kinerja yang dihasilkan. Maka dari itu, motivasi intrinsik maupun ekstrinsik diperlukan sehinggga kinerja guru yang hasilkan akan tercapai secara maksimal
\end{abstract}

KataKunci: motovasi kerja, kinerja, pengelolaan kelas

\begin{abstract}
This study aims to determine the effect of work motivation and teacher performance on classroom management in public elementary schools. This research uses quantitative methods with correlation research design. Sampling technique is done by saturated sample technique for taking all members as sample. Data collection techniques for work motivation, teacher performance and class management in the form of a questionnaire. The data analysis technique used is description statistics, normality test, linearity test is done as a prerequisite hypothesis test, $t$ test for hypothesis testing. The results obtained from the t test results through the calculation of SPSS 16, obtained significance values which indicate that Ho is rejected, which means that Ha is accepted. Thus, work motivation provides an influence on classroom management in elementary schools. On the teacher performance results of the t test results through the calculation of SPSS 16, obtained significance values that indicate Ho is rejected and Ha accepted. Thus the teacher's performance gives an influence on elementary school classroom management. So the conclusion of this study is that there is an influence of work motivation and teacher performance attitudes on classroom management. Therefore work motivation possessed by each teacher influences the resulting performance. Therefore, intrinsic and extrinsic motivation is needed so that the teacher's performance that is produced will be achieved to the maximum
\end{abstract}

Keywords: work motivation, performance, class management

Submitted: 2019, Accepted: 2019, Published: Agustus 2019

ISSN: xxxx-Xxxxx (online), Website: http://jurnal.umus.ac.id/index.php/kontekstual 


\section{PENDAHULUAN}

Guru dan proses pembelajaran merupakan dua hal yang memiliki keterkaitan sangat erat dan mutlak. Artinya guru akan lebih memiliki makna secara edukatif jika guru itu mampu melakukan proses pembelajaran yang baik, tepat, akurat, serta relevan dengan fungsi dan prinsip pendidikan. Untuk mewujudkan idealisme pendidikan itu tidak cukup diimbangi dengan pembelajaran yang efektif.

Undang-Undang Nomor 20 Tahun 2003 Pasal 1 ayat 1 tentang Sistem Pendidikan Nasional menyatakan bahwa: Pendidikan adalah suatu usaha sadar dan terencana untuk mewujudkan suasana belajar dan proses pembelajaran agar siswa secara aktif mengembangkan potensi dirinya untuk memiliki kekuatan spiritual keagamaan, pengendalian diri, kepribadian, kecerdasan, akhlak mulia, serta keterampilan yang diperlukandirinya, masyarakat, bangsa dan negara.

Kkinerja manusia atau yang sering dikenal dengan human performance ditentukan oleh kemampuan (ability) dan motivasi (motivation). Ada yang memiliki motivasi kerja tinggi, rendah dan sedang, semuanya akan berpengaruh terhadap kinerja yang akan dihasilkan bahwa kinerja guru belum maksimal penyebabnya diduga karena motivasi yang dimiliki setiap guru beragam dan kadang berubahubah sesuai kondisi individu masingmasing serta pengelolan kelas jarang dilakukakn terlihat pada tata ruang kelas, kelas yang tidak kondusif, dalam pelaksanaan pembelajaran beberapa guru belum menggunakan berbagai media dan sumber pembelajaran meningkatkan kegairahan belajar anak didik secara berkelompok maupun secara individu .

Berdasarkan latar belakang yang telah di uraikan maka dapat dirumuskan masalah sebgai berikut. 1) Apakah terdapat pengaruh motivasi kerja guru terhadap pengelolaan kelas di SDN Siwungkuk 01 Kecamatan Wanasari Kabupaten Brebes? 2) Apakah terdapat pengaruh kinerja guru terhadap pengelolan kelas di SDN Siwungkuk 01 Kecamatan Wanasari Kabupaten Brebes?

Tujuan di adakannya penelitian ini adalah. 1) Untuk mengetahui pengaruh motivasi kerja guru terhadap pengelolaan kelas di SDN Siwungkuk 01 Kecamatan Wanasari Kabupaten Brebes. 2)Untuk mengetahui pengaruh kinerja guru terhadap pengelolaan kelasdi SDN Siwungkuk 01 Kecamatan Wanasari Kabupaten Brebes.

\section{KAJIAN TEORI}

Ada dua jenis motivasi yaitu motivasi murni dan motivasi ekstrinsik. Motivasi murni sama dengan motivasi intrinsik yaitu motivasi yang timbul dan hidup dari dalam diri sendiri yang merupakan motivasi yang sesungguhnya. Sedangkan motivasi ekstrinsik adalah motivasi yang berasal dari faktor-faktor dari luar[1]. Indikator Motivasi intrinsik ini misalnya, persepsi seseorang mengenai dirinya, minat, tanggung jawab, semangat, harapan pribadi, kebutuhan, keinginan, kepuasan kerja yang dihasilkan. Sedangkan indikator motivasi ekstrinsik misalnya, keinginan mendapat penghargaan atau prestasi, uang, mendapat pujian dari orang lain, dan dorongan dari atasan, hubungan antar pribadi dan kondisi kerja.

Ciri motivasi sebagai berikut[1]: 
1. Tekun menghadapi tugas yaitu dapat bekerja secara terus menerus dalam waktu yang lama dan tidak berhenti sebelum pekerjaan atau tugasnya selesai;

2. Ulet menghadapi kesulitan yaitu tidak putus asa, menunjukkan minat terhadap bermacam-macam masalah;

3. Lebih senang bekerja mandiri;

4. Cepat bosan pada tugas-tugas yang rutin;

5. Dapat mempertahankan pendapatnya yaitu yakin terhadap pendapatnya sendiri dan dapat mempertahankannya.

Dari pendapat yang telah dikemukakan, maka dapat disimpulkan bahwa ciri-ciri motivasi secara umum adalah motivasi itu majemuk, dapat berubah-ubah, berbeda tiap individu, tidak disadari dan tidak terlihat. Ciri motivasi yang terdapat di dalam individu bisa seluruhnya terpenuhi ataupun tidak. Majemuk misalnya tekun dan ulet dalam menghadapi kesulitan. Motivasi dapat berubah-ubah salah satunya disebabkan karena sifat manusia yang mudah bosan. Motivasi yang dimiliki tiap individu berbeda karena sifat manusia yang berbeda, seperti seseorang lebih senang bekerja secara mandiri sedangkan yang lain tidak. Ciri yang terakhir yaitu motivasi tidak disadari, misalnya ketika seseorang dalam keadaan yang mengharuskan mempertahankan diri. Maka orang tersebut secara tidak sadar akan mempertahankan pendapat apa yang telah diyakininya. Motivasi memang tidak terlihat namun dapat diinterprtasikan melalui tingkah laku yang dilakukan oleh masing-masing individu ketika melakukan tindakan untuk mencapai tujuan yang ingin dicapai.

Secara etismologis istilah kinerja merupakan terjemahan dari kata performance yang berasal dari kata to perform yang memiliki arti yaitu (1) prestasi, (2) pelaksanaan, (3) pencapaian dan (4) unjuk kerja atau penampilan kerja[2].

Yang dimaksud dengan kinerja guru merupakan gambaran hasil kerja yang dilakukan guru sekolah dasar terkait dengan tugas yang diembannya dan merupakan tanggungjawabnya[3]. Dalam hal ini, tugas rutin seorang guru adalah mengadakan perencanaan, pengelolaan dan pengadmistrasiaan atas tugas-tugas pembelajaraan dan melaksanakan pembelajaran. Adapun indikator yang berkaitan dengan kinerja guru meliputi: (a) kualitas kerja, (b) kecepatan dan ketepatan, (c) inisiatif (d)
komunikasi.

Masalah pengelolaan kelas dapat dikelompokkan menjadi dua kategori yaitu masalah individual dan masalah kelompok[4]. Selanjutnya peneliti [5] membedakan empat kelompok masalah pengelolaan individual yang didasarkan asumsi bahwa semua tingkah laku individu merupakan upaya pencapaian tujuan pemenuhan keputusan untuk diterima kelompok dan kebutuhan untuk mencapai harga diri. Penggolongan tingkah laku tersebut dapat dilihat sebagai berikut.

1) Tingkah laku yang ingin mendapatkan perhatian orang lain (attention gettingbehavior).

2) Tingkah laku yang ingin menunjukkan kekuatan (power seeking behaviors).

3) Tingkah laku yang bertujuan menyakiti orang lain (revenge seekingbehaviors).

4) Peragaan ketidak mampuan.

Terdapat 6 kategori masalah kelompok dalam pengelolaan kelas. Masalah-masalah yang dimaksud adalah sebagai berikut[6]: 
1) Kelas kurang kohesif.

2) Kelas mereaksi negatif terhadap salah seorang anggotanya.

3) "membesarkan" hati anggota kelas yang justru melanggar norma kelompok.

4) Kelompok cenderung mudah dialihkan perhatiannya dari tugas .

5) Semangat kerja rendah.

6) Kelas kurang mampu menyesuaikan diri dengan keadaan baru.

Dari pendapat beberapa ahli diatas, peneliti menyimpulkan bahwa masalahmasalah pengelolaan kelas secara garis besar dapat diklasifikasikan menjadi dua kategori yaitu masalah individu dan masalah kelompok. Masalah individu yaitu masalah-masalah yang timbul berkaitan dengan kepribadian masingmasing siswa di kelas, sedangkan masalah kelompok berkaitan dengan masalah yang ditimbulkan oleh sekelompok siswa di dalam kelas.

\section{METODE PENELITIAN}

Penelitian ini merupakan penelitian kuantitatif dengan desain penelitia korelasional. Penelitian dilaksanakan di SD Negeri Siwungkuk 01. Pelaksanaan dilakukan pada bulan Maret sampai dengan Juli 2019.

Populasi pada penelitian ini adalah semua guru yang berada di SD Negeri Sigentong 01, SD Negeri Sigentong 02, SDN Dukuringin 02 serta SDN Siwungkuk 01 tahun ajaran 2018/2019 yang berjumlah 8 guru keseluruhan 32 Guru. Sampel pada penelitian ini sebanyak 8 guru SD Negeri Siwungkuk 01 tahun ajaran 2018/2019. Teknik sampel yang akan digunakan dalam penelitian ini adalah Sampling Jenuh (Sensus).

Teknik pengumpulan data dalam penelitian ini adalah 1) Kuesioner dan dokumentasi. Kuesioner ini digunakan untuk memperoleh data tentang motivasi kerja, kinerja guru serta pengelolaan kelas.

Tahap pengolahan data yang dilakukan dalam penelitian ini meliputi.

1. Analisis statistik deskriptif

2. Uji prasyarat Hipotesis

3. Uji hipotesis

\section{HASIL DAN PEMBAHASAN Hasil Penelitian}

Pengaruh antara motivasi kerja dan kinerja guru terhadap pengelolan kelas di SDN siwungkuk 01 Kecamatan wanasari kabupaten brebes.

Berdasarkan uji normalitas di atas menngunakan Kolmogorov-Smirnov diperoleh untuk motivasi kerja menunjukkan bahwa hasil yang diperoleh lebih besar dari $0,05(0,850>$ $0,05)$, untuk kinerja diperoleh hasil $(0,527>0,05)$ dan pengelolaan kelas diperoleh hasil $(0.331>0,05)$ sehingga dapat disimpulkan bahwa data tersebut berdistribusi normal.

Berdasarkan hasil uji linearitas pada output 'Anova Table', diketahui Uji lineritas dikatakan mempunyai hubungan linier bila nilai signifikan > 0,05 . Tabel linieritas motivasi kerja dengan pengelolaan kelas hasil nilai signifikansi liner yaitu 0.868 hasil $(0.868$ $>0,05$ ) uji linier tersebut $>0,05$ jadi hasil uji linieritas anatara motivasi kerja dengan pengelolan kelas bisa dikatakan cocok. Uji lineritas dikatakan mempunyai hubungan linier bila nilai signifikan $>0,05$. Tabel linieritas Kinerja guru dengan pengelolaan kelas hasil nilai signifikansi liner yaitu 0.059 hasil uji linier tersebut $>0,05$ jadi hasil $(0.059>0,05)$ uji linieritas anatara motivasi kerja dengan pengelolan kelas bisa dikatakan cocok.

Berdasarkan tabel pada kolom Equal variances assumed dapat diketahui bahwa nilai $\mathrm{t}_{\text {hitung }}=2,522$ dan 
signifikansinya sebesar 0.000. Dari hasil perhitungan tersebut dapat diketahui bahwa $0.000<\mathrm{a} \quad(0,05) \mathrm{Jika}$ nilai signifikan < a $(0,05)$, atau koefisien terhitung signifikan pada taraf kurang dari 5\% maka dapat dikatakan bahwa terdapat pengaruh antara variable bebas dengan variable terikat secara parsial jadi $0.000<$ a 0,05 variabel motivasi kerja terhadap Pengelolan kelas terdapat pengaruh.Jika nilai signifikan $>$ a $(0,05)$ atau koefisien thitung signifikan pada taraf lebih dari sama dengan 5\% maka dapat dikatakan bahwa tidak terdapat pengaruh antara variable bebas dengan variable terikat secara parsial. Berdasarkan tabel pada kolom Equal variances assumed dapat diketahui bahwa nilai $\mathrm{t}_{\text {hitung }}=19.582$ dan signifikansinya sebesar 0.000 . Jika nilai signifikan < a $(0,05)$, atau koefisien terhitung signifikan pada taraf kurang dari 5\% maka dapat dikatakan bahwa terdapat pengaruh antara variable bebas dengan variable terikat secara parsial jadi $0.000<$ a 0,05 variabel kinerja guru terhadap pengelolan kelas terdapat pengaruh. Jika nilai signifikan > a $(0,05)$ atau koefisien thitung signifikan pada taraf lebih dari sama dengan 5\% maka dapat dikatakan bahwa tidak terdapat pengaruh antara variable bebas dengan variable terikat secara parsial. Jadi kesimpulan dari penelitian ini yaitu terdapat pengaruh motivasi kerja dan kinerja terhadap pengelolan kelas yang signifikansi di SDN Siwungkuk 01 Kecamatan Wanasari Kabupaten Brebes.

\section{Pembahasan}

1. Pengaruh motivasi kerja (X1) terhadap pengelolaan kelas $(\mathrm{Y})$

Diketahui bahwa nilai $t_{\text {hitung }}=2,522$ dan signifikansinya sebesar 0.000 . Dari hasil perhitungan tersebut dapat diketahui bahwa 2,522>2.026 Jika nilai signifikan < a $(0,05)$, atau koefisien terhitung signifikan pada taraf kurang dari 5\% maka dapat dikatakan bahwa terdapat pengaruh antara variable bebas dengan variable terikat secara parsial jadi $0.000<\mathrm{a}$ 0,05 variabel motivasi kerja terhadap pengelolan kelas terdapat pengaruh. Jika nilai signifikan > a $(0,05)$ atau koefisien thitung signifikan pada taraf lebih dari sama dengan 5\% maka dapat dikatakan bahwa tidak terdapat pengaruh antara variable bebas dengan variable terikat secara parsial. Hal ini dapat diperkuat dari penelitian terdahulu yang dilakukan oleh Iskandar (2012) yang dilakukan di SMA Negeri Se-Kabupaten Kendal.

2. Pengaruh antara kinerja $\left(X_{2}\right)$ terhadap pengelolan kelas (Y)

Setelah dilakukan analisis dengan uji $\mathrm{t}$ menggunakan aplikasi program SPSS versi 16, diperoleh bahwa nilai $\mathrm{t}_{\text {hitung }}=19.582$ dan signifikansinya sebesar 0.000. Jika nilai signifikan < a $(0,05)$, atau koefisien terhitung signifikan pada taraf kurang dari $5 \%$ maka dapat dikatakan bahwa terdapat pengaruh antara variable bebas dengan variable terikat secara parsial jadi $0.000<$ a 0,05 variabel kinerja guru terhadap pengelolaan kelas terdapat pengaruh. Jika nilai signifikan > a $(0,05)$ atau koefisien thitung signifikan pada taraf lebih dari sama dengan 5\% maka dapat dikatakan bahwa tidak terdapat pengaruh antara variable bebas dengan variable terikat secara parsial - Jadi kesimpulan dari penelitian ini yaitu terdapat pengaruh motivasi kerja dan kinerja terhadap pengelolaan kelas yang signifikansi di SDN Siwungkuk 01 Kecamatan wanasari Kabupaten Brebes.Hal ini dapat diperkuat dari penelitian terdahulu yang dilakukan oleh Pujiyanti dan Isroah (2012) yang dilakukan di SMA Negeri 1 Ciamis. 


\section{SIMPULAN}

Dari hasil penelitian dan pembahasan dapat ditarik kesimpulan sebagai berikut. Ada pengaruh yang positif dan signifikan antara motivasi kerja terhadap pengelolaan kelas di SDN Siwungkuk 01 Hal ini didukung oleh hasil perhitungan $t_{\text {hitung }}=2,522$ dan signifikansinya sebesar 0.000 . Dari hasil perhitungan tersebut dapat diketahui bahwa 0,000>0.05Jika nilai signifikan $<a(0,05)$, atau koefisien terhitung signifikan pada taraf kurang dari 5\% maka dapat dikatakan bahwa terdapat pengaruh antara variable bebas dengan variable terikat secara parsial jadi $0.000<$ a 0,05 variabel motivasi kerja terhadap Pengelolan kelas terdapat pengaruh.

Ada pengaruh yang positif dan signifikan antara motivasi kerja terhadap pengelolaan kelas di SDN Siwungkuk 01 Kecamatan Wanasari Kabupaten Brebes. Hal ini didukung oleh hasil bahwa nilai $\mathrm{t}_{\text {hitung }}=19.582$ dan signifikansinya sebesar 0.000. Jika nilai signifikan < a $(0,05)$, atau koefisien terhitung signifikan pada taraf kurang dari 5\% maka dapat dikatakan bahwa terdapat pengaruh antara variable bebas dengan variable terikat secara parsial jadi $0.000<$ a 0,05 variabel kinerja guru terhadap pengelolan kelas terdapat pengaruh

\section{REFERENCES}

[1] Sardiman. 2014. Interaksi dan Motivasi Belajar Mengajar. Jakarta: Raja Grafindo Persada.

[2] Barnawi., Arifin, M., 2014. Kinerja Guru Profesional: InstrumenPembinaan,

Peningkatan dan Penilaian. Jogjakarta: AR-RUZZ MEDIA.

[3] Uno, H.B., Lamatenggo. N., 2017, Teori Kinerja dan Pengukurannya. Jakarta: Bumi Aksara.
[4] Yamin, M., Maisah., 2009, Manajemen Pembelajaran Kelas. Jakarta: Gaung Persada Press.

[5] Rohani, Ahmad, 2004, Pengelolaan Pengajaran, Jakarta. PT Rineka Cipta

[6] Lois, J.V., dan Bang, M., 2009, kategori masalah kelompok dalam pengelolaan kelas 